\title{
Loose Connection
}

National Cancer Institute

\section{Source}

National Cancer Institute. Loose Connection. NCI Thesaurus. Code C63055.

Problem associated with the connection of the device being loose or intermittent. 